2009

\title{
Mothers and Their Biracial Children: Growing Up Biracial in a One Race Fits All Society
}

Kristin Felts-Keller

Cedarville University

Follow this and additional works at: http://digitalcommons.cedarville.edu/education_theses

Part of the Race and Ethnicity Commons

\section{Recommended Citation}

Felts-Keller, Kristin, "Mothers and Their Biracial Children: Growing Up Biracial in a One Race Fits All Society" (2009). Master of Education Research Theses. 18.

http://digitalcommons.cedarville.edu/education_theses/18 


\section{MOTHERS AND THEIR BIRACIAL CHILDREN}

GROWING UP BIRACIAL IN A ONE RACE FITS ALL SOCIETY

A thesis submitted in partial fulfillment

of the requirements for the degree of

Masters of Education

By

KRISTIN ANNE FELTS- KELLER

B.A. Sociology, Cedarville University, 2003

2009

Cedarville University 
Please do not duplicate this thesis or use without first contacting Kristin A. Felts-Keller to help ensure participate confidentiality. Thank you. 


\section{CEDARVILLE UNIVERSITY \\ SCHOOL OF GRADUATE STUDIES}

November 4, 2009

I hereby recommend that the thesis prepared under my supervision by Kristin Anne Felts-

Keller entitled: MOTHERS AND THEIR BIRACIAL CHILDREN GROWING UP

BIRACIAL IN A ONE RACE FITS ALL SOCIETY be accepted in partial fulfillment of the requirements for the degree of Master of Education.

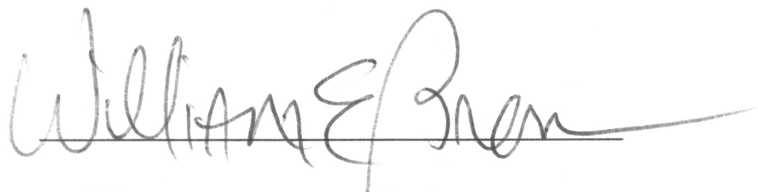

William E. Brown, Ph.D.

President

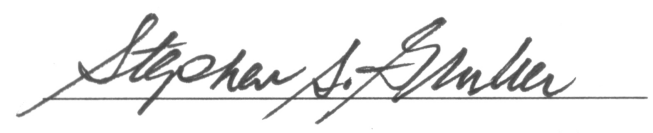

Stephen S. Gruber, Ed.D.

Coordinator, Masters of

Education Degree Program

Thesis Advisor I

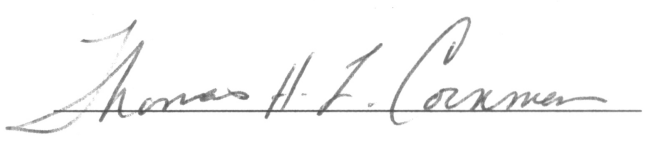

Thomas Cornman, Ph.D.

Academic Vice President

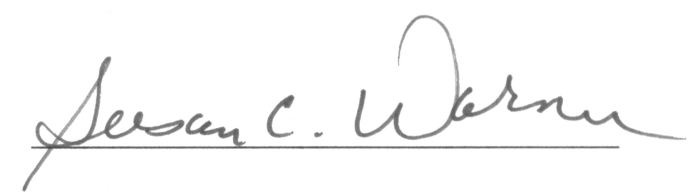

Susan C. Warner, Ph.D

Director of Assessment and

Associate Professor of Sociology

Thesis Advisor II 


\section{Dedication}

This thesis is dedicated to my husband Robert who has put up with the countless hours and stacks books and articles which have consumed my time as I completed my dream of going back to school, to my parents Sandy and Cherie for all of their help and support over the years and always being there for me, and to my grandparents Robert and Elsie Schlegel for encouraging me to always doing my best to succeed at whatever I do. Finally to all of the mothers I interviewed and their wonderful children. I could not have done this without you! Thank you!! 


\begin{abstract}
This thesis is a qualitative study on the Mothers of biracial children and the formation of a biracial identity in a one race fits all society. The goal of this study was to gain a deeper understanding and explore the concerns mothers of biracial children hold for their children. It is not intended to be applied to the general population but it does however, give us an insight into what it means to be biracial, how it is perceived as a race and how the Mothers of these children teach their children to cope with their race and form a positive sense of self-identity.
\end{abstract}


Table of Contents

Chapter One..........Introduction......... 1

Chapter Two..........Literature Review........5

History of the Census..........5

Biracial Identity.........11

Biracial Children.........17

Race as a Social Construct........18

The Role of the Family and Society.........19

Identity Theories.........27

Chapter Three..........Methodology: Qualitative .........38

Chapter Four.........Interview Results .........42

Chapter Five......... Conclusion .........52

Bibliography.........59

Appendixes........ 65

A.........Definition of Terms.........65

B......... Overview of Mothers.........68

C.........Interview Release.........70

D.........Interview Guide.........71

E........IRB Form.........75 


\section{Chapter 1}

\section{Introduction}

The civil rights movement had a significant impact on minorities and people of biracial makeup. As a result of the civil rights movement, race relations have been reshaped through the addressing of racial disparities and empowering minority groups to self-name so that they may validate and declare their standing and existence within society (Bedley, 2008). Through the changing of race relations, the civil rights movement made way for some of the most important court decisions for individuals of all minorities would forever change society and interracial relationships and marriages. One of these important changes effected legal marriages between members of different races.

Despite the 1964 Civil Rights Act and desegregation, biracial marriages were still considered to be illegal until 1967 when the Supreme Court decision Loving $v$. Commonwealth of Virginia outlawed any state laws against interracial marriage (Wardle, 2000). Mixed race marriages have long been a concern in our society because of the potential problems individuals of mixed race can pose to the racial order. Mixed race individuals are forced to navigate their way through the racial system as well as attach themselves in some way to various racial identities (Brunsma, 2005). The United States has long had an issue with racism and discrimination and this has continued to affect mixed families today. American society continues to be very race conscious even though 
there is support for racial integration in public arenas. But still there is an uneasiness regarding the issue of being interracial (Quin \& Lichter, 2007).

Societal discrimination and its rules stem back for years. One such rule that has affected biracial groups has been the one drop rule. This term was once used as a legal definition of not just racial makeup but also included laws which made interracial marriages illegal (Miville, Constantine, Baysden \& So-Lloyd, 2005). The one drop rule mandated that anyone with one drop of African American blood be classified as African American. Taking on African American identity was the only identity for individuals of mixed race because they were no longer considered to be Euro-American (Rockquemore \& Laszloffy, 2003). Because of their mixed racial makeup, they were not considered to be Euro-American due to the fact of their African American heritage. It took many years for biracial individuals to be recognized for the unique individuals that they are. With the change in the 2000 Census with individuals being able to mark more than one race, people of biracial decent finally began to receive the governmental legitimacy and/or recognition which they had been waiting for regarding their claim to their racial makeup. Prior to this significant change in 2000, individuals were only allowed to mark one racial category, thus denying recognition of part of their racial makeup.

With the increasing numbers of biracial families, it is important that they are recognized and given a sense of identity which can be passed on to their descendants. Because of their mixed race, biracial individuals challenge the traditional norms of society and the traditional racial classes, due to the inability to categorize them into just one group. Minorities face rejection from not just the majority, but from other minority groups as well. Individuals of biracial descent have come to realize that race is a social 
construct which is not only arbitrary, but subjective and meaningless (Shih, Sanchez, Bonam \& Peck, 2007). The label which applies to an individual's race publically may be very different from the way one classifies or declares themselves personally (Bratter, 2007).

Being biracial comes with a long list of stereotypes and definitions which have been designated by society. Most of these stem from prejudicial assumptions and discrimination that have carried on into today regardless of the 1964 Civil Rights Act. For biracial individuals, this often means that they must choose their racial identity. This choice is of often based on family, community and social constructs as well as societal influence or pressures (Coleman \& Carter, 2007).

Children of biracial families, often have difficulty finding a sense of self and where they belong in society. There is a constant struggle of self-identity and a sense of not belonging as they are not just one race, but torn between the two. For many, they are left to feel that there is no place for them in society or in some instances, even within their own family constructs (O'Donoghue, 2005). Biracial children must negotiate their race and often experience the chameleon experience effect. The chameleon experience is when individuals must blend into racial groups without standing out or appearing to be different than those around them (Miville, Constantine, Baysden \& So-Lloyd, 2005).

Being biracial requires living a life of multiple identities and being biracial in America; you are living in a society that sees things predominately African American and Euro-American. This then demands one to adhere to one specific race based social on norms (Hull, 2002). This leaves parents of biracial children in a dilemma of how to raise their children within a society which sends mixed and often incorrect signals. 
With the increase of biracial families, more emphasis needs to be placed on family support as well as a sense of community for the children of such families. With the rapid and dramatic change in the United Sates moving from a majority EuroAmerican society to one in which biracial and other former minority groups are on the rise, there needs to be a change in the focus on how we define race and racial identity (Kurashige, 2004).

This study focuses on various theories regarding racial identity as well as exploring how biracial families instill a sense of identity and pride into their children while embracing both cultures and their ethnic history.

This is a qualitative study of biracial families, taking the information gathered from those interviewed and comparing it to already existing research and theories. By doing so, the goal of this study was to achieve a clearer understanding of biracial families, how they perceive race, and how race affects their everyday lives. 


\title{
Chapter Two
}

\author{
Literature Review
}

\section{History of the Census}

In Article I Section 2 of the US Constitution, it is required that Congress conducts an actual enumeration of the US population every ten years. Since 1790, the United States government has taken a count of its population known as the decennial census. Authority to conduct the census was delegated by Congress to be under the direction of the Secretary of Commerce in the US Census Act. The US Census was designed to establish to main goals: first, how many persons are living in the United States and second, where are such persons located. These two goals hold importance because they become the key factors that determine how many representatives each state is allowed in the Federal House or representatives and are also used in how money is allotted and distributed for aid to the various states (Walashek \& Swanson, 2006).

In 1790, the first US Census was carried out by the Secretary of the State Thomas Jefferson. In this census, Native Americans were excluded and African Americans were counted in fractions of three fifths which began the collection of racial data by the US Government (Snipp, 2003). In 1820, the term "colored" was added to the census and in 1840 when the term "colored insane" (in the North) was added to the census resulted in a rather large number. Proponents of slavery used this to argue it was one of the consequences of emancipation (Snipp, 2003). With these changes to the Census, it brought about the first significant challenge to the accuracy of the census. 
With the 1850 census, scholars began to agree that a racial hierarchy existed. This census also took note of the color of those who responded and whether they were free or enslaved. However, slaves were only enumerated with special schedule and were identified as a number along with the name of their owner. It was with the census in 1850 that the term "mulatto" was introduced to acknowledge the existence of those individuals who were of African American-Euro-American and African American-Indian racial makeup. Census respondents were instructed to leave the space blank if the individual was Euro-American, insert a "B" for African American and an "M" for Mulatto (Snipp, 2003).

The 1860 census followed suit of the 1850 census with the introduction of the categories for Chinese and Indian. However, the only Chinese individuals who lived in the state of California were counted. In 1870, Japanese in California were also enumerated into the census and the census continued to enumerate the section for Mulattos for those of mixed race. In 1890, the census began its road to dramatic changes. With the Chinese Exclusion Act of 1882, Chinese and Japanese beyond the state of California were counted into the census (Snipp, 2003).

In 1900, African Americans were no longer subdivided as they had been in previous censuses. The 1910 census used the same racial categories as that of the 1900 census but also added a category for "Other Race". However, the term mulatto continued to be used and was not dropped until the 1920 census. African American was considered African American regardless of how much or now little ancestry was involved as a result of the one drop rule (Snipp, 2003). This assumption and absence of recognizing individuals of African American-Euro-American heritage as mixed suggested that any 
degree of African American ancestry was sufficient enough to be designated as Negro (Snipp, 2003).

The one drop rule for African Americans was institutionalized in 1930 along with the categories for Mexican, Filipino, Hindu and Korean. The one drop rule instituted that any individual of mixed race (Euro-American and Negro blood) as well as anyone part Indian and Negro were to be listed as Negro. The only exception with this rule was an individual of Indian-Negro blood where the Indian blood was more predominate (Bennett, 2000). The term color was not deleted from the census until 1950.

In 1960 the head of the household was allotted to self-identify themselves on the census. This was a fundamental redefinition of the meaning of race. Race began to take on whatever social and personal meaning the respondents chose. However, just because individuals began to be able to designate race on the census, the race which was chosen was still largely driven by society and societal pressures (Snipp, 2003). Before this change in the 1960 Census, census officials decided an individual's race based on hypo descent rules (Hitlin, Brown \& Elder, 2006). This practice based race of mixed race individuals on their subordinate parent. Since Caucasians have been historically dominant within Western world, mixed race children have been assigned the status of their non-Euro-American parent.

With the Civil Rights Movement came great and intense scrutiny of the 1960 Census. Along with the Voters Rights Act of 1960, minorities were able to finally be ensured proper representation. The era of civil rights drastically changed the role of racial statistics (Lee \& Tofoya, 2006). Changes continued to take place within the census from 1970-2000 but it wasn't until the year 2000 that individuals could choose to mark 
more than one race, which finally gave them the recognition that they have so rightly deserved throughout this history of our country and the Census.

Starting the later years of the $20^{\text {th }}$ century to the year 2000 , information was obtained by the Census Bureau through the distribution of census forms by mailing them to every household within the United States. Those who did not respond were followed up through enumerators who were sent by the government to check up on them.

Despite these efforts, there continues to be a portion of individuals who have failed to be accounted for by the US Census Bureau. According to the Bureau, the 1980 census failed to account for 2.8 million individuals nationally. This count continued to fall short in 1990 by 4.2 and 4.0 million people. An accurate account regarding the 2000 census continues to be debated with numbers ranging from 1.8 to 3.3 million individuals being unaccounted for (Walashek \& Swanson, 2006). To help account for these undercounts, the courts passed the Decennial Census Improvement Act in 1991. This Act requires that the Secretary contract with the National Academy of Sciences to study methods which obtain the best and most accurate population count as possible.

Over the past 35 years, the population of biracial individuals within the United States has risen significantly (Coleman \& Carter, 2007). According to the US Census taken in 2000 , there are approximately 6.8 million individuals who classified themselves as two or more races (Coleman \& Carter, 2007). Some of the biracial populations, reported in the 2000 Census, were young under the age of eighteen which meant parents play a significant force in the emergence of a biracial identity (Bratter, 2007).

With the number of biracial individuals becoming greater within American society, a federal task force was created to determine whether or not the census should 
include the classification of biracial. This challenged the traditional notions that race and racial categories have been are discrete, while also extending current thinking regarding interracial group relationships and put stress on political and social policy makers (Cheng \& Lee, 2009).

Population groups such as minorities have historically been an undercounted group in the census. The census change in 2000, allowed Americans to declare two or more racial categories to identify their race (Qian, 2004). This change was driven by the growing population of individuals of multiple races in recent years (Lee \& Tafoya, 2006). Biracial individuals and their advocates were successful in their argument for biracial identification the 2000 census. With the change in 2000 also came a reflection of affirmation of biracial identity by the growing population of those Americans of biracial decent (Lee \& Tafoya, 2006). However, these changes did not go unchallenged.

Some minority groups were those who argued against the creation of multiple racial categories in the 2000 Census. Their argument was in order to preserve their minority numbers as well as to maintain their political influence; such a change would be detrimental (Shish, Sanchez, Bonam \& Peck, 2007). Since society has not given biracial people a place to belong, they have been forced to come up with the answers on their own. Racial categories have no biological basis and are instead, created by society (Goodman, 2000).

Prior to this change in 2000, if an individual did mark more than one race, then the government often decided what race would indeed be claimed (Snipp, 2003). According to the 2000 Census, 1 in 40 (6.8 million) Americans identified themselves as biracial. Out of that population, 42 percent ( 2.9 million) were under the age of 18 
(Bedley, 2008). It is estimated that by the year 2050 one in five Americans will declare themselves biracial on the census (Shih \& Sanchez, 2009).

Within the past ten years an individual's ability to claim mixed race or biracial as an identity has changed drastically. According to the US Census, a biracial individual is someone who chooses to check off membership in one or more of the six census categories of race. (Shih \& Sanchez, 2009). There are six options regarding race and the census. 1) White alone or in combination, 2) Black or African American alone or in combination, 3) American Indian and Alaska Native alone or in combination, 4) Asian alone or in combination, 5) Pacific Islander alone or in combination and 6) Some other race alone or in combination. For the 2000 Census, there were a total of sixty-three possible combinations for the six basic racial categories. This included the six categories for those individuals who reported just one race and fifty-seven categories for individuals who reported two or more races (Census Bureau, 2008).

Biracial individuals are a marginalized ethnic group and prior to the 2000 Census, they had no official recognition as a group. In addition, little evidence exists that minorities are less discriminating to individuals of biracial ethnicity then are nonminorities. Some minorities who identify themselves as African American or African American may see one claiming a biracial identity as taking an anti-African American stance and decreasing the political power of African Americans as a whole. Some EuroAmericans may view claiming a biracial identity as invalid based on physical appearances and/or characteristics as well as on precedent of the one drop rule which stated one drop of African American blood made an individual African American and no other race. This can leave biracial individuals feeling rejected and discriminated against 
by their own race as well as individuals from other races. Biracial individuals are 'both and neither' of their heritages which leads to an interesting and unique standpoint on life experiences (Brackett, Marcus, McKenzie, Mullins \& Tang, 2006).

Of all the individuals who checked more than one racial designation in the 2000 Census a majority were below the age of eighteen. This indicated that parents were heavily involved in the designation of their child's race (Brunsma, 2005). This had been a long awaited change compared to 1990 and earlier censuses where Americans were allowed to indicate only one race of identification (Qian \& Lichter, 2007). The shift in the census represented an acknowledgement of biracial families and their children.

All over America, the numbers of biracial children are on the rise as biracial families are becoming a more common occurrence in today's society. With this shift has come some disagreement with how the census has been handled and the changes which are to come with the upcoming 2010 Census.

The practices which were standard prior to 2000 unjustly denied the biracial population the right to publicly be recognized as a self-conscious and racially distinctive community (Bratter, 2007). We will have to wait and see what changes are to be made in the 2010 Census and what effects any upcoming changes will have for those of biracial identity as well as for society.

\section{Biracial Identity}

While it is clear that biracial individuals do not have any lower level of psychological well-being or social adjustment, they do however face a very unique challenge in handling two or more racial identities (Cheng \& Lee, 2009). Not only are these individuals more likely to face disapproval from extended family members, they are 
also more likely to face disapproval from the community, their neighborhood and peers. Because of this increase in disapproval, biracial individuals must also learn to cope with feelings of isolation and how to reconcile their differences as well as the tensions they face regarding their different racial categories (Cheng \& Lee, 2009). All of these dynamics are influenced by not just racial experiences, but the support and acceptance felt by those whom surround them.

As humans, we often shape our identity based on the perceptions of others. This is no different for biracial individuals. The process however, which biracial individuals use to achieve and choose their racial identity is far more complex as they simultaneously are belonging to more than one racial group (Cheng \& Lee, 2009). Racial identity and formation can be traced throughout history and how not just those who are racially different than the majority perceive themselves, but also how the majority views the minority.

Throughout history, biracial individuals have been characterized with mono-racial identities, especially, those with a minority status such as African American heritage. Today however, things are changing as individuals of mixed race are now asserting an array of identities including mixed race, biracial, biracial, and mono-racial and at times, can vary depending on the social construct in which they find themselves. Of all of these, biracial and biracial are the most common amongst individuals of mixed race (Townsend, Markus, \& Bergsieker, 2009). However, institutional practices still do not always promote or accommodate biracial identity.

In society, skin color is not like eye color, it does make a difference (Howze \& Weberman, 2001). America has long been divided along color lines and has struggled 
with this since the beginning of our birth as a nation. This struggle not only has divided America as a nation and continues to do so to this day, it also divides its citizens, communities, and families.

The struggle with race has become a struggle with America's own sense of self (Sundstrom, 2003). Some have questioned the idea of doing away with the idea of race and erasing it from the social existence that it holds today. However, the idea of doing away with the construct of race is not a social policy which would be beneficial for society nor does it hold any justification morally. Race and problems which are associated with it will not be avoided by simply switching the terminology or racial identity. Wrongful associations which can be evoked by race cannot be magically erased by new terminology regarding race and racial identity.

A color line, which has become very blurred, is how society accepts individuals who are of mixed ethnicity. Individuals who are of biracial ethnicity are often forced into a position in which they must choose to recognize one aspect of their race while denying the other. Biracial individuals should have the choice and the ability to recognize every aspect of their heritage. The term biracial is important because children need to know who they are and come to know every aspect of their ethnic heritage. Biracial families are quickly growing and in the 2000 Census, more than 4.5 million married and unmarried couples indicated that they were from multiple racial or ethnic groups. African American-Euro-American couples account for a third of all interracial marriages making up about $6 \%$ of all married couples (Qian \& Lichter, 2007). The census also showed that 2.8 million children under the age of 18 and 7 million Americans of all ages identified themselves as more than once race (O’Donoghue, 2005). 
Since 1989, more than 100,000 biracial babies have been born resulting in over one million first-generation biracial births (Wardle, 2000). The population of biracial children has greatly multiplied from 500,000 in 1970 to over 6.8 million in 2000 (Jones, Symens \& Smith, 2001). With the increasing numbers of biracial children being born, it is important that they be recognized not just by society, but by their own minority groups and that parents are able to instill a sense of racial identity and belonging into their children.

Biracial children often experience the dual minority status. They find themselves being a minority twice over as they are considered to be a minority in society and also a minority within their own minority groups (Shih \& Sanchez, 2005). Because neither of their parents looks like them, biracial children often have a hard time identifying with their parents and are left to seek out their own sense of identity. Biracial families have needs and experiences that are different from all other types of families.

Identity development is a process which is continuous and begins in early childhood but carries on throughout one's life (McClurg, 2004). This leaves not only biracial children questioning their identity and sense of self, but leaves parents unsure as well as to how to raise their children and how to equally embrace both cultures. Parents and their children need to be able to equally embrace both cultures to enrich their life and so that one race is not elevated over the other.

Minority racial options are not as free as Euro-American race options, as racial distinctions are based primarily on physical appearances. When society associates biracial children solely to one race, parents must become their child's advocate in establishing their standing in both races. Parents as well as society need to acknowledge 
the differences within the child's racial makeup as well as facilitate a formation of pride in their rich ethnicity and acknowledge their families as an interracial family (McClurg, 2004). By acknowledging both of their child's races, this helps to give the child a better sense of identity and belonging and a clearer idea of where they stand within society.

Not enough research exists about biracial families nor is there enough support for families with biracial children. They are left to fend for themselves and parents of biracial children also can experience their own level of opposition by society as well as stereotyped and biased assumptions related to their partner. This makes a sense of acceptance within one's own society a challenge (Kenney, 2002). When parents handle these pressures and establish a way of coping with them, this can give them a greater sense of confidence in raising their child to have a strong biracial identity (McClurg, 2004).

Part of the problem lies within society and the lack of understanding of what it means to be biracial. Not enough acknowledgements have been given to individuals of multiple races nor is there enough focus given to the families regarding the difficulties within society they will face. They not only face opposition within society, but can also experience such opposition from their own minority groups leaving them to be the minority within the minority (Shih, Sanchez, Bonam \& Peck, 2007).

Biracial children have to negotiate shifts between Afro-centric and Eurocentric reference groups and find where they belong in both (O’Donoghue, 2005). Biracial individuals who are of African American and Euro-American race are physically different than their African American and Euro-American counterparts. Their physical appearance as well as genetic composition can be what determine their group identity 
rather than their social role or cultural attributes. The standpoint of biracial individuals, not being a fully a part of a mono-racial ethnic group and not being recognized as an entirely separate racial group, can lead to an increased emphasis on racial groups (Allen, Brackett, Marcus, McKenzie, Mullins \& Tang, 2006).

Children who are biracial are left in limbo as they search for a sense of belonging in a society in which their race has no exact standing. They are left to feel unsettled both in and out of two very different and distinct cultures to which they feel some affinity while they resist others in which society may place them (Jones, 1997). Developing children need to know who they are and where they come from as they are individuals with a combination of race which leaves them in a place where society is still unsure as to where to place them.

A mixed race identity can be experienced in a variety of ways. It can either be ignored; put into a context which is understood, glorified, denied or even reified (Edwards, Ganguly \& Lo, 2006). They are not Euro-American enough to be EuroAmerican nor are they African American enough to be African American and are left in the middle trying to find a sense of identity in both races as well as establishing their own sense of identity and belonging within society. Being and having a biracial identity has taken shape in reaction to the rigid ethno-racial boundaries as well as discourse, that exists and are imposed on individuals of mixed race ethnicity.

Biracial individuals can come across situations where their very identity can become a sense of tension because the idea of biracial identity or mixed race is not accepted or allowed. While claiming their biracial identity has become something that is increasingly desirable to individuals of mixed race, it is not always an option. In some 
instances, choosing multiple races is not something that is even always available to individuals. Limitations still exist today for some biracial individuals when it comes to registering for healthcare, schools, and employment when choosing biracial or more than one race is not an option and they are forced to choose only one. (Townsend, Marcus, \& Bergsieker, 2009).

This inability may not effect all individuals as not all people who are biracial identify themselves as multiple races, however it does effect those who do desire to claim more than one race. Being unable to do so denies their very sense of identity and leaves them without a racial box to which they belong. This limited choice, over time can have lasting affects which include low self-esteem, anxiety, lack of self-motivation and an increased effort to reassert an individual's choice and claim of racial identity (Townsend, Marcus, \& Bergsieker, 2009). The ability to choose individualistic identity is fundamental to the very existence of self-expression in America and the denial of some individuals to do so regarding their race can and should rise a great deal of concern.

Requiring an individual to select just one race to classify is forcing them into a situation in which they are unable to identify themselves as they actually view themselves. Both identity denial and categorization threat has shown to have negative implications on an individual when their social identity is misperceived and/or denied. It is important to understand the experiences of biracial individuals and that requires considering the very multiplicity factors which affect not just the development but the expression of racial identity as well (Townsend, Marcus, \& Bergsieker, 2009). 


\section{Biracial Children}

How does it feel to be the problem? In his essay Souls of African American Folk by W.E.B. Du Bois written in 1903, Du Bois asks this question to fully capture what it meant being an African American man in the United States. This question today continues to take on meaning for individuals who are biracial and in a situation of being in between the two social categories of African American and Euro-American (Sundstrom, 2001). Individuals are often expected to be only one of these racial categories. Biracial individuals have been socially defined as African American for years so it is not surprising that they often identified themselves as African American (McClain, 2008). Individuals who do not fit into such a racial typology become social anomalies and a reminder that race is fluid.

Growing up biracial comes with hurdles in forming a sense of racial identity and belonging within society. It is difficult enough to make your way through life in society's racial categories and not belonging to either group makes it even harder. Options regarding race such as claiming racial group, are not as free as Euro-American ethnic options because racial distinctions are based primarily on physical appearance (Qian, 2004). Individuals who are biracial may classify themselves as one race but are often seen by others in society as another race. While having a unique opportunity to choose how to identify themselves regarding race, such choices may be limited based on societal context (Coleman \& Carter, 2007). This is when the question rises, is race anything more than just a social construct? 
Race as a Social Construct

The very concept of race evolved from the racism and its historical context. For biracial individuals have the unique opportunity to choose how to identify themselves regarding race but these choices are often limited based on the social constructs in which we live (Coleman \& Carter, 2007). Racial identity has come to reside not in our genes but in our minds (Edwards, Ganguly \& Lo, 2007). Identity is formed in relation to other factors in one's environment. Because of this, it is constantly subject to change and switching from Euro-American and African American identities is not uncommon amongst individuals who are biracial (McDermott \& Samson, 2005).

It was Cooley who suggested that we base partially how we see ourselves through the eyes of others. The "looking-glass" self is shaped by our understanding of how others see us (Shah, 2008). For biracial individuals, they are looking through the looking-glass from two different racial heritages. What is reflected back to them by can be a complicated and complex message. Society is not completely positive what to reflect back to these individuals which can lead biracial individuals uncertain of where they stand within society racially.

The color/racial lines have been drawn in a line on shifting sand (Graff, 2001). For many for others, it is not as straightforward. Individuals base their race often on how their social surroundings base race and not on how they perceive it themselves. Thus biracial individuals enter into a forced racial self-categorization scheme (Hitlin, Brown \& Elder, 2006). Race is not a fixed concept but it is often forced into a box in which it does not fit. 
It is absurd to think of and study race as a fixed concept. This absurdity is long surpassed by the necessity of understanding the experiences of those whom identify themselves racially as biracial (Talbot, 2008). Studies today of biracial individuals are not seeking to validate a fixed biological concept or race but do understand the importance of validating the social construct and the impact that race has on an individual's experiences.

\section{The Role of the Family and Society}

Regardless of how biracial individuals may identify themselves personally, they often retreat back to societal stereotypes. The powers of phenotypes are pervasive throughout a biracial individual's life and experienced both within their family as well as within society. Frequently, when biracial individuals are asked how society perceives them, physical appearance, especially skin color, is a commonality. This is especially true and comes into play for individuals who are of African American and EuroAmerican heritage.

Beginning at a young age, individuals are able to identify themselves along a continuum of not just skin color but texture of hair, shape of eyes as well as facial structure. Regardless of how one may label themselves internally or to others, biracial individuals are often labeled by their physical appearance (Talbot, 2008). External forces which drive these labels include the family, friends, school, the workplace, amongst society, and even complete strangers. Regardless of whom it is individuals who are biracial can and often label themselves not necessarily as how they view themselves but on how they are viewed by those around them. 
Identifying oneself as biracial can and often is a process which evolves over time. As racial labels are internalized and reflected on, they change throughout childhood and even into and throughout adulthood. Self-labeling and self-identity can become two very different and distinct things for biracial individuals as they navigate their way throughout society. As biracial individuals differentiates between the two, the journey of finding a sense of self and validation of who they are racially can become a smoother process.

Perhaps one of the biggest struggles growing up biracial, especially being of African American and Euro-American heritage, is dealing with how one is labeled by society. These individuals are under a great amount of pressure by society and how they should identify themselves racially (Talbot, 2008). For some, they begin to question the communities and racial groups to which they belong when they are not accepted by those groups. When rejected by the very group to which they belong, biracial individuals can then question their allegiance to such groups as they are not African American enough to be African American and not Euro-American enough to be Euro-American. They are alienated by their own racial groups and discriminated against by others. These children are in need of assistance as they develop a healthy form of racial identity and alienation only causes them to be in a limbo between their multiple races.

All children are in need of role models. While parents are vital role models for their children, parents of biracial children cannot fully relate to the struggles which they will encounter because they are biracial. Unless a parent is also biracial, they cannot fully understand or comprehend the complexity that comes for their child/children being biracial (Bratter, 2007). While the minority parent may be able to related to these 
children to some degree, they cannot fully understand what it is to be African American and Euro-American in a society which can be, at times a one race minded society.

It is important for children not only to have interaction with other biracial individuals to whom they can relate to, but to also have positive role models who are biracial as well. Not having positive role models can complicate and make creating a sense of self-identity and coming to terms with self-labeling a challenge (Talbot, 2008).

It can be difficult finding a role model who is racially similar but it is very important that biracial children have role models who are of their same racial makeup so that they can have someone to relate to as well as look up to. Searching in society for one's self-image or their racial groups' image and failing to find one can be very disconcerting to biracial individuals. This can lead to a sense of feeling ignored or that they do not exist racially within society (Townsend, Marcus, \& Bergsieker, 2009).

Developing a sense of identity is a complicated process and one that takes time. For individuals who are biracial, this process can become even more complicated as there is a limited language to define their experiences and feelings due to others expressing discomfort as well as disapproval with what they may perceive of as racial ambiguity. For biracial individuals, this can be imposed on them by the demand that they use standard and/or familiar racial labeling as their own racial label. Society needs to move from a mono-racial framework of mind to one which fully integrates all biracial individuals and their experiences and accepts how these individuals label themselves, not how they are labeled by society.

The complexity of being biracial in a society which labels us as one race can have its effects on any individual, but especially children. According to the recent census 
reports from 2000, 53 percent of children were identified with multiple races (Bratter, 2007). While racial classification is a public form of racial identification it can be vastly different from an individual's sense of racial identity. It is important to understand the various ways biracial children are classified to help understand how they are socially identified.

Biracial children are more prone to problems including racism, social problems, psychological issues, low self-esteem, identity problems, social isolation and/or rejection, guilt with siding with one parent's race over the others due to their more complex racial backgrounds (Jackman, Wagner, \& Johnson, 2001). Little attention has been given to them and to their families on how they achieve a positive sense of self-identity and more focus needs to be given to these families and their children. It is projected that around 2050, the US population will switch from the majority Euro-American to the majority being Asian, African American, Hispanic and biracial and Euro-American, becoming the minority (Peterman \& Nyden, 2001).

Today, the biracial population which is reported is very young which suggests that parents are a very significant driving force behind their children's' social and biracial identity. How parents label their children racially can provide a starting point for how their children are not just socialized but also how they come to understand their own sense of racial identity (Bratter, 2007). Children who have one parent who is African American continue to be heavily affected by the one drop rule. These biracial children are more likely to be labeled as well as to label themselves as the minority race rather than as Euro-American (Bratter, 2007). The likelihood that a child is labeled as biracial is varied greatly by the type of racial interaction by which their family is characterized. 
The racial lines that are crossed are very strongly indicative of the degree of flexibility biracial children experience and have regarding their own sense of self identification.

What was once seen as taboo is now seen as a right to express racial identity for those who are biracial. However, claiming such a racial identity can lead to conflict, confusion and maladjustment (Townsend, Marcus, \& Bergsieker, 2009). The process of identity development for individuals who are biracial can present a variety of challenges that a single raced individual would not face. A very substantial challenge to biracial individuals is that institutional practices do not always promote nor do they accommodate biracial identities (Townsend, Marcus, \& Bergsieker, 2009).

As individuals, we desire to have a general motivation for not just collective selfverification but also to perceive and obtain information which is consistent with our social identity. This is no different for biracial individuals and they are perhaps driven by it more as they search for their social identity. Being categorized by others or incongruity between an individual's sense of self and that of another person and/or group can be very disconcerting. Having your identity denied by the group can lead to both identity denial and categorization threat (Townsend, Marcus, \& Bergsieker, 2009). Exclusion from the group to which an individual feels they belong can result in negative emotional responses as well as an increase in the attempt to reassert one's sense of self-identity and effort to regain acceptance into their desired racial group.

There are multiple challenges with associating and maintaining a biracial identity. It is not uncommon for biracial individuals to receive mixed messages from different context and/or people and to then interpret this as indicating miss-categorization or even identity denial. What you may learn from your family on how to perceive your race may 
be very different than that which you receive from your peers. These mixed messages can be a source of tension for those who are still trying to obtain their sense of selfidentity (Townsend, Marcus, \& Bergsieker, 2009).

Rejection by others of an individual's chosen racial identity can continue to challenge and complicate maintaining a biracial identity. A common source of racialidentity conflict comes from the mismatched definitions given to an individual's race by society and one's self-ascribed race. With that can come an increased sense of feeling forced to conform on the expectations and labels given by society and to conform to those which are most predominant. This can leave biracial individuals feeling unable to assert their preferred identity and forced into the identity options provided for them (Townsend, Marcus, \& Bergsieker, 2009). It is important that biracial children and individuals be seen and acknowledged as such and not as a marginalized person labeled as something they are not.

The forcing of only one racial identity to those who are biracial leads to decreased self-esteem. Children already have enough struggles growing up without the added stressors of feeling forced to choose only one race when they are made up of more than one. This can be a very difficult and confusing time for young people and it is important that they are able to embrace both races and feel accepted and acknowledged with the identity in which they choose for themselves

One of the most frequent areas in which biracial children and individuals find themselves being questioned by others regarding their race is in appearance. It is not uncommon for others to misperceive them based on their physical appearance (Townsend, Marcus, \& Bergsieker, 2009). Skin tone is a big factor in how we as 
individuals are defined, not just within society, but within our own families as well. A biracial child may not be as dark skinned as their minority parent but at the same time, may not be as light skinned as their Euro-American parent. This can lead to a very confusing and challenging formation of identity if it is not handled in a way where children can feel free to openly discuss and ask questions regarding their race.

While asserting one's racial identity, this must be done navigating through and in negotiation with socio-cultural environments in which an individual lives (Townsend, Marcus, \& Bergsieker, 2009). Being forced into a racial identity which one does not choose for themselves can lead to feelings of having less control as well as less power within their social environment. This shift can lead to a sense of lower self efficacy and lower motivation to participate within the social group.

Biracial individuals tend to challenge the validity of race and often view race as just a social construction more than those of mono-racial descent (Shih, Bonam, Sanchez \& Peck, 2007). Viewing race as a social construct can be beneficial to biracial individuals. This gives biracial individuals an advantage because when viewing race as a social construct, racial stereotypes can lose their meaning and fail to affect a biracial individual's performance. Race as a social construct also affects a biracial individual's interpersonal as well as social relationships.

Biracial individuals do not tend to give the same meaning and importance to race as individuals of mono-racial identity so biracial individuals often show a greater sense of comfort with interracial relationships and social interaction. Biracial individuals are often more comfortable with such situations than are other minority groups. As well as being more comfortable with interracial relationships, biracial individuals show less 
evidence of implicate racial bias for their multicultural racial group (Paucker \& Ambady, 2009).

An area which is often overlooked is how others perceive biracial individuals. This perception can and does have an effect on biracial individuals and how racial bias can affect them. How others respond to us has a powerful impact on identity as well as psychological well being. The one drop rule continues to be embedded in the minds as well as the practices of our society whether we realize it or not (Sundstrom, 2001). The biracial idiom in society dictates that if you are not Euro-American, then you are African American, brown or yellow. If you are not African American, brown, or yellow then you are Euro-American. If you are not African American or Euro-American you are of mixed race and neither standard racial identity belongs to you. Mixed race or being biracial exists within a society as a third line between African American and Euro-American and between the two racial categories (Pellegrini, 2005). Being biracial or of mixed race can operate as a hinge between two or more distinct races and become capable of unhinging the category of race altogether (Edwards, Ganguly \& Lo, 2006).

A well developed sense of ethnic identity equips people with the ability to be more accepting and more open to individuals from other ethnic groups. Having a secure sense of ethnic identity is associated with a positive intergroup attitude as well as mature intercultural thinking (Phinney, Jacoby \& Silva, 2007). In coming to understand how such things are achieved, we can gain a better understanding on what it means to group up biracial in a world which often labels individuals as just one race. 


\section{Theories}

Race has become an ineffaceable quantity which has determined the shape and the contour of thought and feelings of our human anatomy (Fullbrook, 2001). It has long been ingrained into society and our way of thought and is incapable of being completely erased or removed. Race is an unstable socio-historical construct that intersects in and throughout time, which intersects with other key factors throughout time including gender, social class and sexuality. Race, racism as well as racial identity are not singular nor are they static but are multiple and morphological (Pellegrini, 2005).

Poston and Root in 1990 were amongst the first to publish models for healthy biracial identity formation (Renn, 2008). They were up against a history of skepticism about the possibility of healthy racial identity formation in biracial individuals. Poston and Root offered an alternative to past methods which had hypothesized a marginal existence for those individuals who were biracial (Renn, 2008). Their theories were based both on Root's personal experiences as well as on clinical experiences as counselors.

According to Poston, existing models of minority identity development formation were not accurately reflective of the experiences of biracial individuals and he proposed a new theory which included five levels. These levels were a new and positive model unlike those which stood before it.

The first level purposed by Poston was personal identity. Young children because of their age, hold a personal identity which is not yet necessarily linked to racial reference group. This development does not take place until further on in life as they navigate and obtain a sense of self identity. 
The second level is the choice of group categorization. This level is based on personal experiences and other personal factors such as appearance and cultural knowledge. These factors also include ones which define perceived group status and social support. Individuals choose a multicultural existence which includes both parents' heritage or a dominate culture from one background (Renn, 2008).

Enmeshment and denial compile the third level of Poston's theory. Guilt of not being able to identify with all aspects of their heritage can lead to guilt, anger, shame and even self-hatred. It is important that these all be resolved because it is necessary to do so prior to moving past this level (Renn, 2008).

Once an individual has moved past any feelings of guilt, anger, shame and selfhatred they then move on to the fourth level of appreciation. With this level, individuals begin to appreciate their race by broadening their racial reference group through learning about all aspects of their background. While an individual may than choose to only identify with just one group more than others, they do so by working their way through the process and obtaining such identification through a healthy process (Renn, 2008).

The final level of Poston's model is integration. This is represented by a multicultural existence where individuals value all aspects of their ethnic/racial identities. While they may still only identify themselves mainly with one aspect of their race, individuals still have come to appreciate all aspects of their ethnic background (Renn, 2008).

While the model established by Poston did relate to those before him which he had rejected, he, unlike those before him, accommodated the specificity of biracial experiences. Poston acknowledged the difference between mono-racial and biracial 
identities in the middle three levels of his model. This model has become very useful in understanding biracial identity development as compared to those models which were used for minority identity development (Renn, 2008).

Similar to Poston, (Reen, 2008) Root aligned her model with the models with the early stages of minority identity development. However, Root altered the later stages to reflect the observation that when many biracial individuals with Euro-American heritage reach adolescences, they encounter something unlike other minority counterparts. When biracial individuals reach adolescence, they are unable to reject their majority culture while also being unable to fully be immersed in the minority (Renn, 2008). Root suggested that biracial adolescents, who are partially Caucasian, can enter into a period of turmoil and a feeling of dual existence as they feel that they do not fit into any particular racial group. In response to this, Root established four positive resolutions to the tensions of biracial identity.

The first positive resolution is acceptance of the identity which society assigns. Family as well as a strong relationship with and acceptance by the minority group provide support for those who are biracial with the group that others assume that they belong to. With this resolution comes the second which is identification with both racial groups. However, identification is greatly affected and depends on societal support and an individual's ability to maintain their identity in face of the possibility of resistance from others. Biracial individuals may be able to identify with both heritage groups in spite of resistance by others (Renn, 2008).

The third resolution purposed by Root is identification with just one of the racial groups. This is based on an individual's choose of belonging to one group independent of 
social pressures (Renn, 2008). During this resolution, biracial individuals choose to identify themselves in a particular way and social group. The last and fourth resolution purposed by Root is an individual's ability to move fluidly amongst racial groups but relating most to other biracial individuals regardless of racial heritage. This last phase is known according to Root as identification of a new racial group (Renn, 2008).

Not only did Root account for the impact of racism on identity, but she also introduced the possibility of a new racial group; biracial or biracial. Root suggested that an individual may self-identify in more than one way at the same time and have the ability to move fluidly amongst racial groups (Renn, 2008). The model purposed by Root opened the way for the emergence of new models of biracial identity development and what it means to grow up biracial in a society which places such an emphasis on race.

Being biracial can be experienced in a variety of ways. It can be ignored, denied, put into context, glorified and even be reified or to treat it as if it existed as real and tangible (Edwards, Ganguly \& Lo, 2007).

Several theories exist regarding race and racial awareness. One of which are the three modes of ethnic consciousness by Jacqueline Martinez. According to Martinez there are three modes of knowing when it comes to racial identity. These three modes are (1) unknowing-knowing, (2) pre-knowing-knowing and (3) knowing-unknown (Pellegrini, 2005). It is during these three modes that individuals become aware of their racial identity and an evolution of racial awareness begins to form and take place.

Unknowing-knowing is the initial state in which an individual becomes partially aware of their race and has some understanding that their ethnic and racial heritage is important to who they are and who they might become. Pre-knowing-knowing is marked 
by several factors which include ambiguity, uncertainty, possibility as well as danger where an individual broaches both initial and indirect questions regarding the relevance and importance of their racial heritage as well as family history and looks for people who are in a similar situation. When one then begins to ask questions regarding race and racial heritage as well as their relationship to race they enter into the knowing-unknown phase. Questions are also raised regarding their relationship to racism both past and present and the individual becomes aware that there is an area of unknowingness that both clearly and directly relates to their heritage, life experiences and identity (Pellegrini, 2005).

Another model of biracial identity is based on the development of age-based markers which illustrate racial awareness as developed by Kerwin and Poterotto. This theory acknowledges that there is a variance in identity resolution styles and establishing a public racial identity can and often does differ from what one establishes privately as their racial identity. Influences include personal, societal as well as environmental factors. In this theory it is recognized that biracial individuals can be excluded from their groups of color as well as Euro-Americans (Miville, Constantine, Baysden \& So-Lloyd, 2005).

The first stage is during the preschool stage which occurs up to the age of five when biracial children begin to recognize the similarities and the differences in their physical appearance. This awareness can be a function of the degree of parental involvement and sensitivity to race related issues and the willingness to address such issues (Miville, Constantine, Baysden \& So-Lloyd, 2005). 
The second stage occurs in the entry to school stage when biracial children are in far greater contact with more social groups as well as the possibility of being asked to identify or classify themselves according to mono-racial labels. During the preadolescence stage there is an increased awareness of social meanings which are ascribed to social groups that are characterized by skin color, physical appearance, ethnicity, and religion. It is during this stage that environmental factors also play a role as one enters into a more diverse context as well as direct or vicarious exposure to racism and can heighten an individual in adolescence to their sensitivity to race.

When an individual enters into adolescence, pressures begin to build to identify with one social group and can be intensified by expectations to identify with the racial group of the minority parent. The college/young adult stage is characterized by a continued immersion into a mono-racial group which can be accompanied by an acute awareness of the various contexts where race-related comments can and often are made.

Finally the adulthood stage continues to be characterized by a continued exploration of interest in both race and culture. This includes self-definitions of racial and cultural identity with an increased flexibility to adapt to various cultural settings (Miville, Constantine, Baysden \& So-Lloyd, 2005). Racial identity may begin in childhood but it continues to develop throughout childhood, adolescence and adulthood and is related to positive relationships amongst racial groups.

There is a positive correlation between ethnic identity and intergroup attitudes. This positive link is based on the developmental model of ethnic identity which is an extension of the ego identity formation. Two key processes underlie the ego identity formation; (1) an exploration of identity issues and (2) a commitment to one's decision to 
a direction in life regarding racial identity and life choices such as religion, family, occupation (Phinney, Jacoby \& Silva, 2007).

Individuals, who have neither made a sense of commitment nor explored ego identity, are termed as identity diffuse. Someone who makes a commitment without first exploring is termed foreclosed. An individual who has made some exploration but has yet to make a commitment is in moratorium. Exploration of ethnicity involves learning about one's ethnicity and the implications that it may have for one's life. Identityachieved is when an individual has explored and made a commitment of identity based on those things.

This identity model assumes that change is developmental and as an individual matures, so does too their understanding or racial identity. (Phinney, Jacoby \& Silva, 2007). With commitment comes a decision of what one's racial identity means and how one will live life as a member of that racial community.

Biracial identity and development has been subjected to multiple theorizing. Biracial identity theory should instead, take a multidimensional approach to theorizing and understanding the identities of biracial individuals. Theories need to distinguish between the difference of racial identity, racial identification, and racial categorization of biracial individuals. This multidimensional approach has become advancement in theorizing biracial identity and development (Shih \& Sanchez, 2009).

While the terms racial identity, racial identification, and racial categorization may appear to have the same meaning, each has a specific definition and role in racial development. Racial identity is a personal choice. It is self-chosen and comes with racial self-understanding of oneself and one's racial makeup. Racial identification is not how 
one views themselves but how others view an individual based on their race and/or races. Racial categorization is a chosen racial identity in different context. This theory created by Rockquemore raises an important question, what are the consequences of different racial identities for biracial people (Shih \& Sanchez, 2009)?

One example raised by this question is do differences exist in the psychological health of biracial individuals who choose to identify with either their mono-racial or biracial identity? Biracial individuals who identify with their biracial identities have been found to have a higher sense of wellbeing than those who adopt a mono-racial identity (Cheng \& Lee, 2009). This also suggests that biracial individuals need to perceive their identities as overlapping and compatible in order to have positive outcomes. (Shih \& Sanchez, 2009). These can be measured by using the Biracial Identification Scale.

The Biracial Identification Scale measures the individual differences in the ways which biracial individuals manage their multiple racial identities. According to Cheng and Lee, biracial integration consists of two subscales (a) racial conflict - feelings of tension amongst component racial identities and (b) racial distance - perceptions of how to separate the component racial identities (Shih \& Sanchez, 2009). The lower the racial distance and the lower the racial conflict, individuals are more likely to have a higher sense of biracial pride as well as biracial experiences.

Roccas and Brewer in 2002 purposed four strategies used by biracial individuals in coping and developing their biracial social identity. Biracial individuals may also manage their multiple social identities using one of four strategies. They may do it through intersection or identifying with the intersection of all their racial groups. With 
this strategy, individuals identify with others who are like them and of the same racial make-up finding a commonality which they share with others. (Cheng \& Lee, 2009).

Individuals may also manage their multiple identities through dominance or identifying with just one of their social groups which is more dominant than the other. For many biracial individuals of Euro-American and African American heritage, these individuals will identify with their African American ethnicity since it tends to be the more dominant of the two in physical appearance.

Compartmentalization, also known as identification, is another known strategy used by biracial individuals. Here, individuals are in limbo between their two races and indentify with being African American in one setting while being Euro-American in another. Their decision is based on the situation and which race is most applicable to their given situation and setting (Cheng \& Lee, 2009).

Lastly, biracial individuals may choose to use the merger strategy in which they indentify with both of their social groups simultaneously. Individuals identify with both of their racial groups and are accepting of both in any given situation or setting (Cheng \& Lee, 2009).

Consistent with the theory purposed by Roccas and Brewer, their theory is supported by evidence that biracial individuals tend to use a very similar set of strategies to negotiate the borders between their different racial categories. These strategies include having both feet in two racial groups meaning that an individual is accepting and a participant in both of their racial groups which is consistent with their identity.

Also included as a strategy is shifting both the foreground and the background as an individual move between various social contexts as defined by race (Cheng \& Lee, 
2009). This is very similar to Roccas and Brewer's compartmentalization strategy in that an individual is African American when it suits them and Euro-American when it suits them. Here, individuals are able to negotiate between the two and be one of both races at any given time or setting.

Another similarity to Roccas and Brewer's strategy is that biracial individuals can consciously choose to sit on the border of their race and experience something which is defined as a hybrid border of racial identity (Cheng \& Lee, 2009). Hybrid border for a biracial individual is identifying with those who are similar to you in race and racial makeup.

Some individuals who are biracial identify with one camp while visiting the other when necessary. This strategy is almost identical to Roccas and Brewer's dominance strategy in where an individual goes back and forth between the two races and tends to relate to the dominant race most often but also, can relate to their less dominant race when necessary (Cheng \& Lee, 2009).

For an individual who is biracial, not one theory or strategy is particularly used at all times nor are they always stable. For biracial individuals, their ways of coping and relating to race vary across the given context of their situation and throughout their lives. Strategies and development evolves over a life time for these individuals. As humans, we all change our identification based on constraints and situations. This is no different for an individual who is biracial as they do change their identification based on their individual constraints, cognitive resources, as well as contextual factors and situational cues that make their social identity more or less salient (Cheng \& Lee, 2009). 
While all theories have had an impact in how society views race and racial identity, parents continue to play a large role in the development of their child's racial identity. Parents serve as the first teachers and play a primary role in the development in racial and ethnic identity. It is through the recognition and the integration of all racial/ethnic identities that a biracial individual can develop a secure and a healthy biracial identity (Coleman \& Carter, 2007). 


\section{Chapter Three}

\section{Methodology: Qualitative}

Parents are one of the key factors in how a young person views race and how they determine what race they are. Parents' role in racial identity can help children build a solid foundation upon which to build a sense of identity, value and understanding regarding racial make-up and racial values. While societal factors are also play a role in racial identity, it is the parents who play the largest role in how one views their own race. Parents are active participants in their child's identity formation as well as their identity development (Schacheter \& Ventura, 2008).

For this study, I performed a quantitative explorative study regarding biracial children and their parents. This method included interviews with open ended questions to gain a deeper and better understanding of the topic. I choose to do qualitative as I desired to gain a further understanding on how families who are biracial approach the subject of race as well as how they viewed it. I felt that those who were most experienced for my subject to be interviewed were those who lived it every day living the life as biracial individuals.

The focus was only on the children of African American-Euro-American racial make up to ensure homogeneity. No other racial groups were focused on nor were any other surveys distributed. This study was based solely on interviews. I interviewed ten families and narrowed my findings down to seven based on which results were most 
applicable to this study. By finding the commonality amongst these families, they became the primary focus of the study.

The process of acquiring interviewees took place over a period of a couple months. Individuals were first contacted by either, a letter, phone call or email. All interviews used for this study were audio-taped with the permission of the individual and all individuals interviewed signed a release form stating they were aware of the purpose of the interview as well as the presence of an audio-tape recorder. Children were not interviewed although some did accompany their parents during the interview process. The decision of whether or not the child/children were present during the interview was left solely up to the parents. Children who did attend were allowed to join in the conversation if they so desired. Out of all the interviews, only one child was present who wished to express his thoughts regarding his race and what race meant to him. However, because he is a minor, his comments will not be included in this study

My sample study included mothers of biracial children. The fathers of these children were not intentionally excluded from this study. Letters were sent out to the parents of biracial children and it was only the mothers whom showed interested and were willing to participate in this specific study.

The goal of the study was to find out how mothers cope with the stereotypes set forth by society and how they deal with them. I asked if there were any stereotypes individuals had experienced not just from being involved in an interracial relationship, but also as being a parent of a biracial child. Another focus was how they anticipate such stereotypes will affect their children and how they will teach their children to deal with such opposition providing them with a solid foundation to build upon 
To ensure homogeneity, all interviewees were mothers of African AmericanEuro-American children. A total of ten mothers were interviewed from the central Ohio area. The snowballing effect was used to gain more participants to ensure saturation. Families were not included who have adopted biracial children or anyone that is outside the African American-Euro-American racial make-up. I did not survey any other minority groups. Interviewees were narrowed down in phases through an elimination process.

Homogeneity was also kept through the use of consistent interview questions and all questions were opened ended to ensure that the individual was answering how they desired, not how they felt led. All interviews were kept confidential and no identity will be revealed at any time. To ensure confidentiality, pseudonyms have been given to all of the mothers and will be used for this study. All individuals were offered to see a final copy of the transcript from their interview and could ask for something to be excluded if they so desired. No interviewees asked for a copy of their transcript nor did any request that anything from the interview process to be excluded from this research. Copies of tapes were also offered but none desired for any information regarding the interviews.

Interviews were held in private settings or wherever the individual desired to meet for the interview process. This was done so that individuals felt that they were able to fully express themselves without being concerned anyone would overhear any of the conversation and to ensure that they felt as comfortable as possible during the interview. Interviews ranged from thirty to forty-five minutes and the length of the interview rested solely on the individual and how much they desired to share or discuss. A basic outline was followed for each of the interviews but there was also an allowance to further the 
discussion if there was an area in which the individual wished to discuss in more detail. All individuals were allowed to speak freely and were encouraged to do so to ensure validity to this study.

All interview recording were transcribed and notes were taken during the process and were applied to this research thesis. Nothing was added or taken away from the recordings and everything was transcribed to ensure that no one was misquoted during the transcription process.

Every individual interviewed has been given a pseudonym. It is in no way related to their true identity but a name has been randomly assigned to them. All quotes or references to these mothers will be done so by referring to the name given to them to help ensure confidentially regarding their true identity.

Mothers ranged in ages twenty-seven to mid-fifties. All of the mothers interviewed, with the exception of one, had more than one child. All children had fathers who were actively involved in their lives. Two of the mothers were no longer married to the father of their child but still had a good standing relationship with them. Fathers were all aware of the interview taking place but none accompanied the mothers although it was an option if they so desired.

Confidentiality was kept throughout the process. No names were used in the making of this thesis and no names were or will be released to the general publics' knowledge. All tapes, transcripts, and notes are kept in separate locations to ensure individual privacy and confidentiality and will not be made available for public use in order to keep confidentiality of all individuals. 
However, this study is not to be applied to the general population as it is a limited sample size of mothers in the Central Ohio area. Limitations include a sample biased and not enough mothers were interviewed which would make this study applicable to the general population. 


\section{Chapter Four}

\section{Interview Results}

Throughout the interview process, commonalities did reoccur amongst all individuals. These themes will become the focus and how they apply to already existing research in the area of biracial identity. The five reoccurring themes were 1) openness to race as a childhood, 2) vision of explaining race to their children, 3) acceptance of children being shunned by some and the obstacles and hurdles that come with it, 4) Not naïve to obstacles and fear of children being rejected by one racial group, and 5) instilling a sense of pride of racial identity.

\section{The Mothers:}

Sandy: African American Mother of Two

Becky: Euro-American Mother of One

Wendy: Euro-American Mother of One

Heidi: Euro-American Mother of One

Michelle: Euro-American Mother of One

Rebecca: Euro-American Mother of Two

Megan: Euro-American Mother of Two

Openness to Race as a Child.

One of the initial questions asked of each of the mothers was how race was explained to them as a child. This was asked so that a comparison could be made to how 
they then described race to their own child/children. The desire was to see if there was any commonality on how racial perceptions are passed on from generation to generation or if any of the individuals interviewed had created their own viewpoint and belief about race.

Most of the mothers interviewed, did not recall any specific conversation with their parents or at any time in their lives having a specific meaning set forth for them regarding race. One mother recalled race never really being explained in her family but it was never an issue either. In fact, all of her siblings are in interracial relationships and all have felt support from their immediate family in the process.

"I don't remember anything (race) being explained to me. We didn't have a lot of mixed in my immediate family as far as my mom and her siblings, there wasn't any mixed there, the interracial started when we kids became adults. All of my siblings are interracial relationships and my cousins. So their children have the same skin color as my children". - Sandy

The mothers interviewed all ranged in age from late twenties to fifties but none could recall ever having a specific expectation or definition given to them regarding race.

"Race was never explained. My parents never differentiated anyone from anyone else". - Wendy.

Because of the openness regarding race and the acceptance most of the mothers felt growing up within their own families, a majority of those interviewed did not experience any negative stereotypes regarding race and individuals of a different race. Fortunately, this gave these mothers a foundation upon which to build their understanding and perceptions of race that was not tainted or contaminated with negative misperceptions.

Vision of Explaining Race. 
All of the mothers had clear visions and expectations of how race would be explained to their children and how they would instill value and confidence within their child/children's racial identity. Since many of the children of these mothers are still very young, some of the mothers were not quite sure when they would begin explaining race to their children and how some individuals may treat them based on their racial makeup.

"Its (race) going to be rolled out in pieces as she's dealing with it. I'm not going to be naive to think as she grows up in her first primary years that life is going to be easy and not having to deal with 'who are you'? At what level that is (the difficulty), I will have to give her the tools and information and how to deal with those types of people". - Heidi.

One aspect of explaining race and defending their child/children's race that was reiterated by many of the mothers was how they would address issues of race depending on the situation. Mothers of these children recognized that kids will be kids and will ask questions regarding race and friends of their child/children may say things not knowing or understanding the situation.

"A lot of his classmates will ask about his skin. I'll tell them his skin is in between his dads and mine". - Becky.

Children are curious and are bound to ask questions. These mothers understand that and welcome and encourage such questions. They are happy to explain their child/children's heritage and racial make up to those who will listen. This is a way to also further understanding and acceptance amongst those who do not have an adequate understanding of biracial individuals, especially children. Children are often innocent in their preconceptions of race and only reiterate what they are taught.

"Children are children and are so innocent". - Becky.

"The kids themselves would be fine but they are engrained with things at home". - Michelle 
These mothers feel that if they can help educate other children, especially friends of their child/children then they can help put an end to any cycles of discrimination based on one's race. One mother described it best as:

"We were two adults who loved each other and decided to have a baby. Race wasn't an issue. We didn't even look at that". - Wendy.

While mothers are welcoming and willing to address questions of race with children, especially those children with whom their children interact, negativity from adults is an entirely different issue. Adults, who come across as condescending to their children or treat them negatively based solely on their race is an area which mothers feel very defensive. Several mothers stated that in situations involving an adult reacting negatively to their child/children because they are biracial, they would address that individual.

"As a mother, I will take that protectiveness. If it is a child that's one thing if it's an adult, believe it will get addressed". - Heidi.

Although race was not a major focus that they placed on their child/children's identity, they were also well aware of the complications that may occur growing up biracial in a one race fits all society. Acceptance, Obstacles and Hurdles.

Another commonality amongst these mothers was that they wanted their children to understand that there will always be those people out there that do not like you regardless of your race. People base their perceptions and opinions of us on multiple things, not just race. There will always be someone somewhere that does not like you for who you are based on what you are.

“There are people that have their own beliefs and don't feel it's right and I have conversations with my son that there are going to be people that won't like him 
because he has a Euro-American mom and a African American dad and that he will have to deal with it. But everyone has their own preference. My biggest thing is I want to teach him is you just move on and not everyone is going to be nice. And there will always be 101 different reasons why, not just because of race". Becky.

These mothers want their children to be proud of who they are but also want their children to understand that there are obstacles and hurdles that come with being biracial. Mothers of biracial children don't want their children to feel that people reject them solely on the basis of race, but there are other reasons that people base judgments on us as individuals.

"I don't know how I'm going to explain the part about people about not liking you because of the way you look. I hope and pray he doesn't face that but if he does then we'll go from there". -Becky.

While racial makeup may indeed play a large role, it is not the only thing which they will be judged on throughout their lives. Regardless of what one is judged on within society today, none of the mothers could quite grasp judging someone based on their race. It didn't make any logical sense to them and some were left struggling to find a reason behind it and finding a way to wrap their mind around the way society things regarding race and racial makeup.

“I just don't understand hating someone you don't even know just because of what they look like. I guess that is sin but I try to rationalize it in my mind and I can't'. - Megan.

Some of the mothers interviewed stressed throughout the process their faith and how their faith in God helps to give them the strength to get through the emotional hard times and fears they have for their children being biracial. These mothers all understand that God loves us as individuals based on who we are not what we are. They rely on this faith and place their hope and faith in a God who will help them through the hard times 
and also find their sense of value in Him, not in a society which judges individuals based on outward appearances.

One of the major commonalties amongst all of the mothers interviewed was that they are not naïve to the obstacles and discrimination their children may face as a result of being biracial however, race is not something they themselves focus on.

"I really don't think about race a whole lot to be honest unless I'm forced to. I don't see that my husband is African American and my son is biracial. We are a family that loves each other". - Megan.

Mothers of these children do not focus on the racial makeup of their children as much as they do on who their children are as individuals. Race is a social construct that society has created and mothers interviewed did not place as much emphasis on race as does society. While none of the mothers interviewed deny race or downplay its importance in understanding oneself and establishing a healthy sense of identity, the mothers did not focus on their child/children's racial makeup of any major importance. Race to these parents did not matter, what mattered was that their children were happy and healthy and became successful and productive individuals within our society.

"Being biracial, it means nothing but you have to be conscious of it. You have to be aware of what your child is dealing with". Heidi.

\section{Fear or Rejection by Racial Groups.}

A commonality of being rejected by those of their own two races was another key aspect re-occurring with the mothers interviewed. They feared that their children would not fully belong to either group; their Euro-American or African American heritage and that neither of their two distinct racial groups would fully recognize them as members and accept them for who they are. Their desires is that their children are not looked as 
being biracial but labeled African American by their Euro-American counterparts and labeled Euro-American by their African American counterparts.

"I know a lot of people in the African American community are going to look at him and not consider him African American and Euro-American people automatically assume he's African American but he's both. I'm hoping they don't but you never know. I want him to have a place to belong". - Wendy.

Like any parent, these parents want their children to have a place to belong. The concern is that both racial groups will not fully accept them as individuals and he/she will be left between two different and two very distinct worlds. These mothers do not view their children as another statistic or substandard, because they are biracial. They are their children and they love them for every aspect of who they are, including their race, both races.

"My daughter is not substandard just because she is biracial. But biracial should reflect the merging of those two races". - Heidi.

It was evident throughout the interview process with all of the mothers, that instilling a sense of pride in who their children are was very important. Some families would often joke amongst each other about conversations they have had regarding race with individuals who aren't always aware of the situation.

"We didn't make too much of a big deal of it (race). He does not look racially mixed, because he looks Euro-American. We have lots of times joked when we will tell each other what people have said in front of us not knowing he is African American". - Michelle.

Most of the mothers could each recall a time while out in public someone would say something to them regarding their child/children's physical appearance. Everything from individuals asking them where their child was adopted, from, to the odd and uncomfortable looks that come with being involved in an interracial relationship. 
Sometimes the awkwardness came from people not asking questions but instead just staring because of the uncertainty of the situation.

"We didn't get a lot of questions because people weren't quite sure what he was". - Michelle.

Thinking about race and focusing on it has become something that has been forced upon these families by society. Race wasn't an issue to any of the mothers interviewed and they found themselves focusing on race in ways they never had quite anticipated. They all understood that entering into an interracial relationship and having children would come with its complications but none saw their children as the complication. Society was the problem and the amount of importance that race is stressed and forced upon individuals. Children who are biracial are just as important in society as an individual who is mono-racial.

All the mothers interviewed were well aware of the challenges and obstacles that their children may face growing up biracial in a world which sees African American and Euro-American. However, none felt that their child/children's race was a hindrance but instead, something which would help build a stronger sense of character about themselves. All felt that their child had a rich culture upon which to build upon and aim to raise their children well aware of the races which run through their blood. Instilling Pride.

While all were aware of their child's mixed race, none thought it was particularly relevant who whom their child was and who they would become. Most did not put much thought into their child/children's race and instead saw them as individuals living in a society which places such an extreme emphasis on race and racial identity. The shift of 
changes lies within society itself regarding race and the importance which is stressed upon racial identity.

One of the questions asked during the interview process was regarding the hopes and dreams these mothers hold for their children. The hopes and dreams are like that of any parent, that their child/children are happy, healthy and productive.

"My hopes and dreams are the same for anyone's children that they grow up to be successful and not have to deal with a lot of things. That they be successful and reach their hopes and dreams. My dreams and hopes are like any parent that they succeed and are happy". - Sandy.

They also hope that there will be a shift in society and that their children will be seen for the wonderful individuals that they are, not for the color of their skin.

"Don't judge a book by its cover. When you peel away the outer we're all just the same. I love my son so much that is all I can say I'm so proud of him regardless of that (race). I try not to make it an issue because for me, it's not". - Becky.

All of the mothers interviewed of these children hope that their child/children will not have to deal with any difficulties because of their racial makeup. Mothers are aware that it is highly unlikely that their child won't ever encounter someone or something and their racial makeup becomes a hindrance, but they are also hopeful that they have equipped their child/children with the tools and knowhow to handle the situation.

Race to these mothers is not downplayed or ignored however; it is not how they see their child/children. They do not look at their child/children and immediately think 'they're biracial'. They look at them with the love and concern that every parent does. Race does not matter nor does it make them love their child/children any more or any less. None of these parents downplay the biracial heritage which flows throughout their child/children's veins however, it is not a driving factor in how they see their children nor does it play the only role in who, their child/children will become. 
"I value my roots very much. I value where I came from and my daughter will know exactly where she came from. You may look like this but you have this too. It is (my race) just as important to me as his African American background". - Heidi.

There is much more to us than race. Our race may help shape us and mold us into the individuals we are but it is not the only factor in determining who we will become.

These mothers see their children as something much more than another statistic. They do not want their children forced into a society which bases their existence and value on who they are based on their race.

"I don't like to make it a racial thing, it's not about race". - Rebecca.

"I want him to have a place to belong". - Wendy.

There is much more to these children than their race. They are all beautiful children with dreams and aspirations of their own. While some still dream of being astronauts and doctors, others are pursuing their dreams navigating through a society which often, places social stereotypes on them based on the color of their skin. It is impossible to justify the cruelty and the ignorance of society. But this is a battle the parents of these children face every day as they raise their child in a society where some continue to focus on race and where you belong. 


\section{Chapter Five}

\section{Conclusion}

Today, our world is becoming more and more racially integrated as we become increasingly more global, and mobile. This means that more individuals are identifying and claim membership in more than one racial group making recognizing the biracial population a noteworthy demographic ethnic group (Cheng \& Lee, 2009). The social pressures to choose or identify with only one group can push biracial individuals into choosing a singular racial identity which otherwise, they may not choose for themselves (Herman, 2004).

Race is one of the axis that define inequality within society (Snipp, 2003). There are new emerging racial identities with no clear terminology or methodology with which to understand and know how to deal with them. The mixed-race population is at the core of changing the race relations within the United States but we have no clue as to whether biracialism is demolishing or reinforcing racial hierarchies (Rockquemore, Brunsma \& Delgado, 2009). Biracial children face substantial obstacles which have been imposed by society in their development of a competent sense of self-identity.

Selecting a racial category for biracial individuals is a very significant act. The connection between subjective identity and racial identification is very profound as well as meaningful as it can conjure an identity that society demands from such an individual 
(Hitlin, Brown, \& Elder, 2006). Race and ethnicity have become not just about how an individual identifies himself/herself but also how they are indentified by society.

Families need to be aware of the obstacles that their children and family will face and know how to cope throughout the various aspects of growing up biracial in a society which still places an emphasis on race. Parents may also face extended family members may relate ambivalently and even reject biracial children due to the very fact they are a result of a mixed union or races (Crawford \& Alaggia, 2008). The mothers interviewed for this study were not immune to this. Sandy, a married mother of two recalled how her husband family at first rejected her children. It wasn't until after the death of a family member that some family members became involved. It took losing another member of the family for them to realize the importance of family regardless of race.

Social support from the family and exposure to diversity has shown to help in the decision process of either identifying with the majority or the minority group. Family environment can promote a stable understanding and meaningful biracial identity when there is an integration of both identities (Crawford \& Alaggia, 2008). You cannot expect a biracial child, who is raised in a home where one of their racial heritages is ignored to have an adequate grasp on whom they are racially. Ignoring an aspect of racial heritage, is denying a part of who the child is. Both races need to be accepted and integrated into the child's life and their understanding of who they are racially.

For some of the mothers including Wendy and Megan, neither could recall a time growing up where their parents differentiated one race from another. Race wasn't an issue so when they entered into biracial relationships and had children, race wasn't even considered to be a problem. For these mothers, they had no mixed preconceptions 
regarding race and inter-racial relationships. These are things that they plan on instilling in their own children as they raise them in a society that can at times, state otherwise.

Parents are expected to raise their children to be competent individuals of society as well as to teach their children to live within a socio-cultural niche. Parents of biracial and ethnic minority children must also educate their children about discrimination and disparaging stereotypes through racial socialization (Hudley \& Wakefield, 2007). Mothers Michelle and Rebecca both recalled times where they had to explain to their children who are now in their late teens and early adulthood that people may discriminate against them based on the color of their skin. These mothers had more experience than some of those younger mothers due to the fact that their children are older. But regardless of the variety of ages amongst those interviewed it continued to be a commonality amongst all the mothers interviewed. That they are aware of the discrimination their children may and will face because of their mixed raced and also, how to best educate them to handle those stereotypes set before them by society.

Racial identities which are instilled by parents provide a solid foundation which shapes the future identity of biracial children (Qian, 2004). The role of family is a key influence in the formation of racial identity. Being aware of and understanding of racial issues is key in parental awareness of what it means growing up biracial. Parental understanding is vital because children are most likely to see their parents support, validation and assurance as a primary source when seeking out their racial identity. These mothers are having some of the most joyful times of their lives as explained by Heidi. They will support their children regardless of their choices in life and embrace every aspect of them, including all aspects of their race. 
The concepts of race and racial identity are also influenced by the degree of a family's openness to discuss race and racial issues. Even though these mothers may not be able to relate to the complexities of growing up biracial, their openness and willingness to validate their children is vital in decreasing any feelings of isolation or invalidation. (Crawford \& Alaggia, 2008).

Race is a social construct within our society that has come to force such an extreme emphasis on an individual's race. While race is important as it is a part of an individual's heritage, it is not the sole factor in determining who you will become. These mothers have the same dreams for their children as their mono-racial counterparts do. However, these mothers must also be aware of the struggles and difficulties their children are going to face because they are biracial. They are not naive, just find it extremely unfortunate that their children, who are so innocent are up against such a battle regarding finding their standing point regarding race.

It is a one race fits all type of world. Of all the biracial individuals in today's society, many are children. These children are left in limbo as they search for a place to belong while treading the waters of a racially driven society. The one drop rule continues to affect those of biracial decent as society no longer views them as either race. True, there have been significant changes within society regarding not just race but also in the recognition of biracial individuals. With the changes in the US Census, it has also been recognized that being biracial is becoming more common as there are more interracial marriages and relationships.

Individuals should act as unencumbered selves meaning that we should be bound only to what we choose for ourselves and not to the traditions and expectations set by the 
society into which we were born and by which we were raised. Skin color is not something that is chosen by us but is decided by who our parents are. Thus, it should not bind us nor should it shape our actions or our affections (Howze \& Weberman, 2001). While there should still be pride in whom you are and where you came from racially, it should not be the sole driving factor in who we become. This was a strong underlying commonality amongst the mothers interviewed. That they wanted their children to be proud of who they are racially but not to allow it to drive where or where not they would go in life.

Identity integration is of high importance and it is essential to a positive sense of racial identity. A positive sense of biracial identity is comprised of both positive and negative experiences for an individual of biracial decent. By taking both the positive and the negative, individuals are able to integrate the two into the formation of their own sense of individual identity.

The mothers interviewed for this study all wished to instill a sense of identity into their children of pride and acceptance not just of themselves, but also of others who are like them or different. Knowing that their children are sure to face opposition from others because of their race, it is the hope and dream of these mothers that their children then take this experience and form it into who they will become. Walking away a stronger and better person regardless of what others say, do or act towards them based on their race.

You can take all the theories and all the perceptions of race and apply it to society. However, these mothers are not interested in theory and the ideas of society implemented onto their children. To them, this is real life, not some text book theory or a 
how to manual of being biracial. It is far more deeper to them than that. These are their children, born out of love between two individuals who looked beyond the issue of race and brought child/children into this world that they love and would do anything for. While they are not naïve to society and the terms, stereotypes and discriminations that still exist of race, to them, race means nothing. Their child/children are not race to them, they are their children whom they love and would do and sacrifice anything for. You can take as much theory as you want and try to apply it to these families but to them, theory is not what they base how they raise their child/children. They base raising of their child/children on the values and faiths on which they believe. Theory, while it has its importance and does play a role within society on how we understand and perceive something such as race, is not a clear cut map of which these families follow. Are they aware of it, yes. Do they follow it as an instruction manual of how to raise their family, no.

It is difficult to transcend race entirely when living in a society which can place such importance upon it. Being biracial to an individual can to them be inconsequential but while still at the same stressed at the same time (Crothers \& K'Meyer, 2007). Our diversity as individuals is something to be valued and there is value in gaining an understanding not just on the racial heritage that creates us, but understanding the forces behind that drive us. Race is a social construct and it is not something that has come naturally to us or are innate to our very nature.

Although commonalities did reoccur throughout the interview process and were fairly consistent with those interviewed, it cannot be applied to the general population. Because this was only a sample group based in central Ohio, it cannot be generalized for 
all biracial families. The focus was on the biracial family unit and how they deal with the daily issues, struggles, complications and the joys of being an interracial family. The hope of this study was to get a look into the biracial family unit and see how they view themselves as well as how they feel society views them. My intent was to seek out cultural meaning without the intention to apply or generalize it to the population as a whole but to use the information gathered and use it so we may further understand the many threads which make up vast woven cultural society.

Race is a large part of who we are as individuals. Each of us has a vast array of family heritage and we should be proud being the individuals that we are. While race is a large part of who we are, it does not determine what we are. Race does not determine the individual you become but it can be the building block upon which you build who you are. As children begin to become aware not just of racial groups but of identity as well, they then begin to identify themselves with the racial group to which they feel they conform to. Racial self-identification is a primary process for self-definition in racial groups (Hitlin, Brown, \& Elder, 2006).

The future for these children and their families looks bright. Throughout history, changes have been made for equal rights, recognition, support, and acceptance of these families. However more acknowledgement needs to be given to these individuals and they must be recognized for their racial identity in full, not just in part. While we have come a long way, we still have a ways to go regarding race and the acceptance of those who are biracial. As a society, we have to be willing to accept individuals for who they are, all races included. 


\section{Bibliography}

Bedley, C. (2008). The formation of multiracial identities. American Sociological Association, 2008 Annual Meeting, 1-18.

Bennett, C. (2000). Racial categories used in the census, 1790 to the present. Government Information Quarterly, 17(2), 161-180.

Brackett, P.B., Marcus, A., McKenzie, N., Mullins, L., Tang, Z., \& Allen, A. (2006). The effects of multiracial identification on students' perceptions of racism. The Social Science Journal, 43, 437-444.

Bratter, J. (2007). Will "multiracial" survive to the next generation?: The racial classification of children of multiracial parents. Social Forces, 88(2), 821-849.

Brunsma, D.L. (2005). Interracial families and the racial identification of mixed-race children: Evidence from the early childhood longitudinal study. Social Forces, 84(2), 1131-1157.

Cheng, C., \& Lee, F. (2009). Multiracial identity integration: Perceptions of conflict and distance among multiracial individuals. Journal of Social Issues, 65(1), 51 - 68.

Coleman, V.H., \& Carter, M.M. (2007). Biracial self-identification: Impact on trait anxiety, social anxiety, and depression. Identity: An International Journal of Theory and Research, 7(2), 103-114.

Crawford, S.E., \& Alaggia, R.A. (2008). The best of both worlds? Family influences on mixed race youth development. Qualitative Social Work, 7(1), 81-98.

Crothers, A.G., \& K'Meyer, T.E., (2007). "I was Black when it suited me; I 
was white when it suited me": Racial identity in the biracial life of Marguerite Davis Stewart. Journal of American Ethnic History, 26(4), 24-49.

Du Bois, W.E.B. (1903). The souls of black folk. Chicago, Seventh Edition 1907.

Edwards, P., Ganguly, D., \& Lo, J. (2007). Pigments of the imagination: Theorizing, performing and historicizing mixed race. Journal of Intercultural Studies, 28(1), $1-13$.

Fullbrook, E. (2001). Conceptual displacement: From the natural to the social. Review of Social Economy, LIX(3), 285-296.

Goodman, A. H. (2000). Why genes don't count (for racial differences in health). American Journal of Public Health, 90(11), 1699-1702.

Goodman, G. S., Sayfan, L., Lee, J. S., Sandhei, M., Walle-Olsen, A., Magnussen, S., et al. (2007). The development of memory for own- and other-race faces. Journal of Experimental Child Psychology, 98(4), 233-242.

Graff, E.J. (2001). Being Black and White. The American Prospect, 12(16), 42-46.

Hall, R. E. (2002). Biracial sensitive practice: Expanding social services to an invisible Population. Journal of Human Behavior in the Social Environment, 5(2), 29.

Herman, M. (2004). Forced to choose: Some determinants of racial identification in multiiracial adolescence. Child Development, 75(3), 730-748.

Herring, R. D. (1995). Developing biracial ethnic identity: A review of the increasing dilemma. Journal of Multicultural Counseling \& Development, 23(1), 29-38.

Hitlin, S., Brown, J.S., \& Elder, G.H. (2006). Racial self-categorization in adolescence: multiracial development and social pathways. Child Development, 77(5), 12981308. 
Howze, Y., \& Weberman, D. (2001). On racial kinship. Social Theory and Practice, 27(3), 419-436.

Hudley, C., \& Wakefield, W.D. (2007). Ethnic and racial identity and adolescence wellbeing. Theory into Practice, (46)2, 147-154.

Jackman, C.F., Wagner, W.G., \& Johnson, J.T. (2001). The attitudes towards multiracial children scale. Journal of African American Psychology, 27(1), 86-99.

Jones, N.A., \& Smith, A.S. (2001). Census 2000 brief: Two or more races, U.S. Census Bureau. Retrieved July 20, 2008, from http://www.census.gov/prod/2001pubs/c2kbr01-6.pdf.

Kenney, K.R. (2002). Counseling interracial couples and multiracial individuals: Applying a multicultural counseling competency framework. Counseling and Human Development, 35, 1-12.

Kerwin, C., \& Ponterotto, J. G. (1993). Racial identity in biracial children: A qualitative investigation. Journal of Counseling Psychology, 40(2), 221-231.

Kurashige, S. (2004). The many facets of Brown: Integration in a multiiracial society. The Journal of American History, 91(1), 56-68.

Lee, C.Y., \& Kee, F. (2009). Multiracial identity integration: Perceptions of conflict and distance among multiracial individuals. Journal of Social Issues, 65(1), 51-68.

Lee, J., \& Bean, F.D. (2004). America’s changing color lines: Immigration, race/ethnicity and multiracial identification. Annual Review of Sociology, 30, 221-242.

Lee, S.M., \& Tafoya, S.M. (2006). Rethinking Us census racial and ethnic categories for the $21^{\text {st }}$ century. Journal of Economic and Social Measurement, 31, 233-252. 
McClain, C.S. (2008). African American by choice: Identity preferences of Americans of African American/Euro-American parentage. The African American Scholar, $34(2), 43-54)$.

McClurg, L. (2004). Biracial youth and their parents: Counseling considerations for family therapists. Family Journal, 12(2), 170-173.

McDermott, M., \& Samson, F. (2005). White racial and ethnic identity in the United States. Annual Reviews of Sociology, 31, 245-261.

Miville, M. L., Constantine, M. G., Baysden, M. F., \& So-Lloyd, G. (2005). Chameleon changes: An exploration of racial identity themes of multiracial people. Journal of Counseling Psychology, 52(4), 507-516.

O'Donoghue, M. (2005). White mothers negotiating race and ethnicity in the mothering of biracial, black-white adolescents. Journal of Ethnic \& Cultural Diversity in Social Work, 14(3), 125-156.

Pauker, K., \& Ambady, N. (2009). Multiracial faces: How categorization affects memory at the boundaries of race. Journal of Social Issues, 65(1), $69-86$.

Pellegrini, G. (2005). Multiracial Identity in a Post-Civil Rights Era. Social Identities, 11(5), 531-549.

Peterman, W., \& Nyden, P. (2001). Creating stable racially and ethnically diverse communities in the United States: A model for the future. Social Policy \& Administration, 35(1), 32-47.

Phinney, J., Jacoby, B., \& Silva, C. (2007). Positive intergroup attitudes: The role of ethnic identity. International Journey of Behavioral Development, 31(5), 478490. 
Qian, Z. (2004). Options: Racial/Ethnic identification of children of intermarried couples. Social Science Quarterly (African American well Publishing Limited), 85(3), 746766.

Qian, Z., \& Lichter, D. T. (2007). Social boundaries and marital assimilation: Interpreting trends in racial and ethnic intermarriage. American Sociological Review, 72(1), $68-94$.

Renn, K. (2008). Research on biracial and multiracial identity development: Overview and synthesis. New Directions for Student Services, Fall 2008, 13-21.

Rockquemore, K. A., \& Brusma, D. L. (2002). Socially embedded identities: Theories, typologies and processes of racial identity among black/white biracials. Sociological Quarterly, 43, 335-356.

Rockquemore, K.A., Brunsma, D.L., \& Delgado, D.J. (2009). Racing to theory or re-theorizing race? Understanding the struggle to build a multiracial identity theory. Journal of Social Issues, 65(1), 13-34.

Rockquemore, K. A., \& Laszloffy, T. A. (2003). Multiple realities: A relational narrative approach in therapy with black-white mixed-race clients. Family Relations, 52(2), 119.

Schachter, E.P., \& Ventura, J.J. (2008). Identity agents: Parents as active and reflective participants in their children's identity formation. Journal of Research on Adolescence, 18(3), 449-476.

Shah, J. (2003). The motivational looking-glass: How significant others implicitly affect Goal appraisals. Journal of Personality \& Social Psychology, 85(3), 424-439.

Shih, M., Bonam, C., Sanchez, D., \& Peck, C. (2007). The social construction of race: 
Biracial identity and vulnerability to stereotypes. Cultural Diversity \& Ethnic Minority Psychology, 13(2; 2), 125-133.

Shih, M., \& Sanchez, D. T. (2005). Perspectives and research on the positive and negative implications of having multiple racial identities. Psychological Bulletin, 131(4), 569-591.

Shih, M., \& Sanchez, D. (2009). When race becomes even more complex: Toward understanding the landscape of biracial identity and experiences. Journal of Social Issues, 65(1), 1-11.

Snipp, M. (2003). Racial measurement in the American census: Past practices and implications. Annual Review of Sociology, 29, 563-588.

Sundstorm, R. (2001) Being and being mixed race. Social Theory and Practice, 27(2), 285-307.

Sundstrom, R. (2003). Arrogance, love and identity in the American struggle with race. Social Theory and Practice, 29(1), 159-172.

Talbot, D.M., (2008). Exploring the experiences and self-labeling of mixed-race individuals with two minority parents. New Directions for Student Services, 123, 23-31.

Townsend, S.M, Markus, H.R., \& Bergsieker, H.B. (2009). My choice, your categories: The denial of multiracial identities. Journal of Social Issues, 65(1), 185-204.

U.S. Census Bureau, Population Division. (2008). Racial and ethnic classifications used in the Census 2000 and beyond. www.census.gov/Retrieved October 27, 2009. http://www.census.gov/population/www/socdemo/race/racefactcb.html

Wakashek, P.J., \& Swanson, D.A. (2006). The roots of conflict over the US census 
counts in the late $20^{\text {th }}$ Century and prospects for the $21^{\text {st }}$ century. Journal of Economic and Social Measurements, 31, 185-205.

Wardle, F. (2000). Multiracial and multiethnic students: How they must belong. Multicultural Perspectives, 2(4), 11-16.

Wardle, F. (2007). Multiracial children in child development textbooks. Early Childhood Education Journal, 35(3), 253-259. 
Appendix A

Definition of Terms

1964 Civil Rights Act: Made segregation by race illegal (Wardle, 2000).

1967 Loving v. Commonwealth of Virginia: Supreme Court Decision which outlawed any state laws against interracial marriages (Wardle, 2000).

Biracial Identity Model: Integration is the key to the positive development of identity through recognition and the integration of all ethnic identities (Coleman \& Carter, 2007). Biracial Self-Identification Measure (SBE): Questions which refer specifically related to racial identification as a choice (Coleman \& Carter, 2007).

Biracial: A child born of a coupling of two distinctly different raced parents and thus, possesses a combination of both physical characteristics of the different racial ancestries (Herring, 1995).

Categorization Threat: The experience of being miscatergorized as an individual of the incorrect group (Townsend, Marcus, \& Bergsieker, 2009).

Chameleon Experience: Strategies developed to help an individual fit in with more than one racial group (Miville, Constantine, Baysden \& So-Lloyd, 2005).

Comparative or Equivalent Approach: Mono-racial and biracial individuals being equivalent (Shih \& Sanchez, 2005).

Dual Minority Status: An individual caught between two cultures but does not belong to either (Shih \& Sanchez, 2005). 
Ethnic Identity: A complex construct which includes commitment and a sense of belonging to an individual's ethnic group, positive evaluation of that group, interest and knowledge about the group, and positive involvement within the group's activities and traditions (O’Donoghue, 2005).

Ethnicity: Broad groupings of Americans based on race and culture of origin (O’Donoghue, 2005).

Euro-American: Caucasian or being of white decent.

Forced-Choice Dilemma: Feeling forced to choose one identity and reject the other (Shih \& Sanchez, 2005).

Interracial Family Unit: Families of two racial make ups (McClurg, 2004).

Interracial Marriage: Two individuals of different race entering into marriage (Miville, Constantine, Baysden \& So-Lloyd, 2005).

Mono-racial: Identifying oneself as just one race (Coleman \& Carter, 2007).

Multiethnic: An individual or child whose acknowledged identity is recognized from two racial ethnicities (Wardle, 2007).

Biracial: An individual or child whose racial identity is from two or more ethnicities (Wardle, 2007).

One Drop Rule: Any individual with one drop of African American blood being classified as African American (Rockquemore \& Laszloffy, 2003).

Phenotype: Physical appearances and features (Talbot, 2008).

Race: Consciousness of status/identity based on ancestry and color (Lee \& Bean2004). Racism; The efforts of a dominant racial group to exclude a dominated racial group from sharing in both the material and symbolic rewards of both status and power (Hull, 2002). 
Self-labeling: A label shared with the rest of society by a biracial individual (Talbot, 2008).

Self-identity An internalized sense of self and who one is racially (Talbot, 2008).

Societal Pressure: The level of pressure individuals feel from society, peers and family to identify as mono-racial.

US Census: A mandated Census by the US Government taken every 10 years. The results are used to allocate congressional seats, electoral votes, and government funding. 


\section{Appendix B}

Overview of Mothers

Sandy: Married Mother of two.

African American

$30+$ years old

Husband is the father of both of her children.

Both she and her husband work fulltime.

Extended family is involved on both sides.

Becky: Single Mother of one

Caucasian

$25+$ years old

Child's Father is actively involved

Is engaged to an African American man, but has no children by him.

Works full time.

Extended family is involved on both sides. Step-Father shows some reservations but is not attributed solely to the mixed race of her child although it is a factor.

Wendy: Single Mother of two, but only one is biracial and being raised by her.

Caucasian

$25+$ years old

Child's Father is actively involved

Does have another child but the child does not live with her but has been primarily raised by other family members. Sees the child some but not on consistent basis. The other child has a Euro-American father who is not actively involved. This child was not included in the study or any of this research.

Heidi: Mother of one

Caucasian

$25+$ years old

Living with Father but not married. The couple does plan on getting married but has no immediate intentions to do so.

Both sides of the extended family are actively involved.

Michelle: Married Mother of one

Caucasian

$50+$ years old

Son does not live at home but both parents are actively involved in his life.

Both sides of the extended family are actively involved. 
Rebecca: Married Mother of two

Caucasian

$50+$ years

Both children out of the home but both parents are actively involved.

Both sides of the extended family are actively involved.

Megan: Married Mother of two

Caucasian

$30+$ years

Both sides of the extended family are actively involved although the father's

family is located further away. Attempts are made by both sides of the family to visit as often as possible. 
Appendix $C$

Interview Release Form

*A copy was kept for myself the interviewer and all individuals interviewed were offered a copy for their own records if they so desired.

\section{Interview Release Form}

I this interview hereby give my permission and willingly participate in (Your Name Here)

given by $\underline{\text { Kristin A. Keller }}$ to be used in part to fulfill her thesis on biracial children and their parents on

\section{(Today's Date)}

I understand that any information shared may be used in her paper while my identity will be kept confidential and nothing regarding myself or my family will be released.

Anything said that is later used in the completion of her thesis will not have my name, the name of my child, or any form of reference back to me or my family to indicate my participation. I will be given a specific code which will be unique only to me and known only to Kristin. All transcripts, notes, or audio tape from this interview will be kept in a secure location separate from each other and will be available to my review if I so desire.

I understand that this interview will be audio taped as well as notes taken during the interview process. I thereby give Kristin authorization to use this interview and will answer any questions to the best of my ability. If there is a question that I do not feel I can answer, or do not feel comfortable answering I understand that I have the right to ask Kristin to move onto the next question and continue the interview process.

(Print Name Here)

(Sign Name Here and Date)

(Kristin A. Keller) 


\section{Appendix D}

Interview Guide

All mothers were asked the following questions. Each interview did have differentiation then that of other mothers interviewed. The mothers were encouraged to share freely and each given an opportunity to speak their mind further regarding their conceptions of race. It was encouraged for the mothers to make the interview their own and for them to be open and share what it means to them to be a parent of a biracial child.

Start interview with this is Kristin and today's date is and today I am interviewing who is the parent of a biracial child.

- What is your name?

- How old were you when you had your child? How old are you now?

- What is the name of your child and how old are they?

- Tell me about your child? What do they like to do, what's their favorite food, color, sport, etc. What makes them tick?

- What is the racial makeup of your child?

- Do you have other children that are of different racial makeup as well?

- How did your family react when they found out you were going to have a child that was biracial?

- Did anyone have any reservations or react negatively?

- How did your friends respond?

- What about the other parent of the child did their family and friends respond in a positive manner? 
- Overall, did you feel you had a good support system during your pregnancy?

- Were you ever afraid or nervous about telling people you were pregnant? Did being pregnant with a biracial child affect you at all when sharing your pregnancy?

- How did you mark race on your child's birth certificate?

- How do you explain race to your child?

- How was race explained to you as a child?

- How do you explain their race?

- Has your child ever asked why their skin color is different than yours? If so, what did you say? If not, how do you think you would respond?

- Since the birth of your child, has there been anyone that has negatively reacted to their mixed race?

- Since your child is of multiple racial make-up, how do you embrace race? Do you incorporate both cultures into their life or do you embrace one more so then the other?

- Are there any fears or reservations you have for your child regarding their mixed race?

- Do you feel that society has changed enough that today, your child will not have to face any adversity regarding their mixed race?

- What are your hopes and dreams for your child?

- What do you want your child to understand about race and being biracial?

- What does being biracial mean to you?

- If you could tell your child anything about what it means to be biracial, what would you say?

- How will you instill a sense of pride into your child regarding their race? 
- If you could tell society one thing about what it means to grow up biracial what would you say?

- What do you want to change in society regarding race?

- How will you tie your child's sense of self identity into their race?

- Is there anything else you would like to share? 
Appendix E

IRB Form Copy

\section{Cedarville University}

Student Name(s) and email: Kristin Keller: Nitsirkkeller@hotmail.com

Faculty Name(s): Dr. Susan Warner and Dr. Steven Gruber

External Researcher Name(s) and contact information: N/A

Date: Summer Session II 2008

Project Title: Biracial Children and Identity Theory

1. Summarize the main steps of your research plan.

I will be interviewing 10-20 parents of biracial children in hopes to find a correlation amongst them in order to help determine how parents of biracial children help their children to determine their racial identity as well as fears that parents hold for children of biracial decent. Our society labels individuals most often as one race and I want to research how parents help their children identify with their multiple races.

2. Describe any potential harm you foresee occurring to participants in your study.

Race continues to be a very sensitive subject in our society. I will have to be sure that I am very careful and aware of how and what I am asking the families which I am interviewing. I also need to be in tuned with what they are saying and know when to stop if the interview becomes to be too much or too emotional.

3. If foreseeable potential harm may occur to your research subjects, describe what steps you intend to take to minimize this harm or to keep it within acceptable ethical and moral parameters.

If I feel that I have crossed any lines or upset any of my participants, I will stop the interview and take a few steps back from the interview process and give my individuals a moment to relax. I will do my best to comfort or be of any assistance. If they desire to halt the interview I will do so and not push the issue any longer.

4. Provide the anticipated benefits of your study. If there are anticipated significant risks to subjects, weigh these two factors from your perspective.

My hope is that my study will help to open eyes of anyone who reads my thesis regarding children of biracial decent and their place within our society and such children should not be labeled as just one race. Race is a very important aspect of what makes up 
our identity and how society labels us can have a dramatic affect on all of us, especially children. Although races is a very sensitive subject, I feel it is one that continues to need to be addressed and biracial children should be given every opportunity to discover who they are and accept both races which creates their genetic make-up.

5. Will subjects provide informed consent regarding their participation in the study? Yes.

6. If subjects will be provided with informed consent regarding their participation in the study, identify the means by which that will occur. Individuals will give consent.

I will acquire both written and verbal consent during the interview process

7. If subjects will not be provided with informed consent regarding their participation in the study, explain why this will not be necessary or why the cost/benefit warrants not doing so.

\section{N/A}

8. Identify the anticipated beginning and ending dates of your connection with human participants.

I hope to begin the process by the end of October and hope to have my interviews completed by December. I want to be sure to have the process done thoroughly and don't want to drag anything out longer than necessary.

9. Describe what you anticipate human subjects in your research study will do (describe the activities they will participate in, what they will be asked to do or be observed doing, types of questions they will be asked, or behaviors you would expect to observe)

My participants will engage on one on one conversation with me during the interview process. Each interview will last 15-20 minutes and will be asked questions regarding their children and their race. Each interview will consist of the same questions amongst families to ensure homogeneity amongst the interviews. I will be asking questions such as how they identify their child (as one race or two), how they incorporate different race within the family, any potential hurdles they feel their child may face, etc.

10. Describe how you will ensure that the publication or presentation of your results will ensure the anonymity of those participating in the study.

No names will be used in my thesis. Families will be identified by number only. Names will never be released and will maintain confidential and known only unto myself. I will keep all tapes and transcripts in a secure location as well as kept separate from one another. I will not leave any such information in my car at any time and will keep it either in my possession or in my home at all times. I will not use any public computers and will save things to a flash drive designated for thesis purpose alone.

11. Are you seeking expedited review of this research project?

Yes. I will go before the board for thesis review. I will admit I am very anxious about it but I am confident that I will be prepared as I will do my best to ensure that 
everything is done to my best potential and will not release my thesis for review until I am ready to defend it.

Proposals should be forwarded to: Andy Runyan, Associate Vice President, Academic

Administration: arunyan@cedarville.edu, Founders Hall Room 3, Phone (937) 766-3840. 